\title{
Modulation of Axon Diameter and Neurofilaments by Hypomyelinating Schwann Cells in Transgenic Mice
}

\author{
Joan S. Cole, ${ }^{1}$ Albee Messing, ${ }^{2}$ John Q. Trojanowski,, ${ }^{1}$ and Virginia M.-Y. Lee' \\ 'Department of Pathology and Laboratory Medicine, University of Pennsylvania Medical School, Philadelphia, \\ Pennsylvania 19104, and 'Department of Pathobiological Sciences, School of Veterinary Medicine, University of \\ Wisconsin-Madison, Madison, Wisconsin 53706
}

\begin{abstract}
Studies of peripheral nerves in two different lines of hypomyelinating transgenic mice support the hypothesis that myelinating Schwann cells exert a significant influence on key biological properties of axons. The mice contain transgenes combining the peripheral myelin protein zero gene $\left(P_{0}\right)$ promoter and either the diphtheria toxin $A$ chain gene product or the SV40 (simian virus 40) large T antigen. The consequences of peripheral nerve hypomyelination on axon diameter, neurofilament (NF) density, and NF phosphorylation were analyzed. The sciatic nerves of the $P_{0}$ diphtheria toxin A transgenic mice (DT) evidenced the most severe hypomyelination, and this was associated with a dramatic decrease in NF phosphorylation plus a marked increase in NF density. In contrast, the sciatic nerves in the $P_{0}$ SV40 large $T$ antigen transgenic mice (SV40) were not as severely hypomyelinated and there was a milder decrease in NF phosphorylation plus a more modest increase in NF density. Further, the sciatic nerves in both lines evidenced a decrease in axonal caliber without any change in NF content. Taken together, these studies provide strong evidence indicating that myelinating Schwann celis exert a significant influence on axon caliber by modulating NF phosphorylation and NF packing density in the axons of peripheral nerves. Thus, key biological properties of axons are modulated by signals transmitted from myelinating Schwann cells to axons of peripheral nerves.
\end{abstract}

[Key words: neurofilaments, hypomyelination, transgenic mice]

In the PNS, Schwann cells and axons have complex interactions beginning in the developing nervous system and extending into adult animals. The Schwann cells develop into two different populations (i.e., one type myelinates large-diameter axons, while the other envelopes small-diameter axons but does not form myelin), and Schwann cells are thought to play an important role in determining the morphology and physiological functions of axons. Previous studies showed that PNS axons relayed in-

\footnotetext{
Received Oct. 29, 1993; revised May 6, 1994; accepted May 11, 1994.

We thank Dr. Mark Black for critical reading and suggestions in the preparation of this manuscript. Justina Melanie Minda and Beth Moran are thanked for assistance in the electron microscope analysis. This work was supported by Grant NS 18616 (V.M.-Y.L.) and NIH Training Grant 5-T32-RR-07032-05. A.M. is a Shaw Scholar of the Milwaukee Foundation.

Correspondence should be addressed to Dr. Virginia M.-Y. Lee, Department of Pathology and Laboratory Medicine, Hospital of the University of Pennsylvania, Maloney Basement Room A009, Philadelphia, PA 19104.

Copyright (C) 1994 Society for Neuroscience 0270-6474/94/146956-11\$05.00/0
}

formation to the surrounding Schwann cells, leading to the induction of myelination by Schwann cells in contact with axons (Bray et al., 1981). Myelin sheath thickness and the internodal length were considered to be directly dependent on axonal caliber (Fraher, 1978). However, more recent experiments suggest that Schwann cells can cause local changes in the morphological properties of the axon. For example, the diameter of the axonal processes of cultured neurons is modified by the presence of Schwann cells (Windebank et al., 1985; Pannese et al., 1988), and the initiation of myelination by a Schwann cell will produce a local enlargement in axonal diameter relative to adjacent regions of the same axons that are in contact with nonmyelinating Schwann cells (Pannese et al., 1988). Further, Parhad et al. (1987) have reported changes in the organization of axonal NFs in segments where focal demyelination was produced.

Alterations in the properties of hypomyelinated axons in the mutant Trembler mouse also suggest that axons respond to signals from Schwann cells. For example, hypomyelination of the axons in these mice results in a reduction of axonal diameter in the hypomyelinated regions (Aguayo et al., 1977; Pollard and McLeod, 1980; Perkins et al., 1981), altered slow axonal transport, altered regeneration of the axons (de Waegh and Brady, 1990), decreased NF phosphorylation, and increased NF density (de Waegh et al., 1992). Hence, it now appears that Schwann cells modulate important properties of the neurons, including axon diameter.

The diameter of the axon is not predetermined and it changes during devclopment and regeneration (Hoffman et al., 1985). Several studies correlating cytoskeletal composition and axonal diameter during neuronal development and regeneration suggest that the caliber of myelinated axons is primarily dependent on NF number (Friede and Samorajski, 1970; Lasek et al., 1983; Hoffman et al., 1985). Additionally, studies of the "quiver" mutant quail provide direct evidence of the importance of NFs in achieving and/or maintaining normal axon caliber (Yamasaki et al., 1992).

NFs belong to the family of intermediate filament (IF) proteins. NFs are made by the copolymerization of three proteins with predicted molecular weights of 62,96 , and $116 \mathrm{kDa}$ in mice (Julien et al., 1986; Lewis and Cowan, 1986; Levy et al., 1987). The low- (NF-L), middle- (NF-M), and high- (NF-H) molecular-weight NF proteins share with each other and with other IF proteins a highly conserved central $\alpha$ helical rod domain of approximately 310 amino acid rcsidues, which is responsible for the formation of coiled-coil structures in IFs. Antibody decoration experiments (Hirokawa et al., 1984) and partial proteolysis of NFs (Carden and Eagles, 1983; Julien and Mushynski, 
1983) suggested that the NF-L protein is part of the NF backbone, while NF-H and NF-M are involved in the formation of sidearm projections on the outside of the filament (Hisanaga and Hirokawa, 1988; Mulligan et al., 1991). A unique feature of NF-M and NF-H proteins is their long carboxy-terminal tail domains that contain multiple repeats of the sequence Lys-SerPro (KSP), called KSP segments (Meyer et al., 1987; Lee et al., 1988a). These represent the major phosphorylation sites in NF proteins (Lee et al., 1988a,b). These charged amino acids at the periphery of the filament, and in sidearm projections may induce charge repulsions that increase the spacing between NFs (Carden et al., 1987; Lee et al., 1987, 1988a). The projections may also contribute to the control of axon caliber through changes in phosphorylation (de Waegh et al., 1992).

Here, we studied the effect of hypomyelination on NF phosphorylation, NF density, and axonal caliber in two recently developed lines of transgenic mice. The promoter used to target the transgene expression to myelinating Schwann cells is the myelin protein zero gene $\left(\mathrm{P}_{0}\right)$. It is expressed only in myelinating Schwann cells (Brockes et al., 1980; Mirsky et al., 1980; Trapp et al., 1987; Martini et al., 1988) and it is positively regulated by contact with axons (Politis et al., 1982; Poduslo and Windebank, 1985; LeBlanc et al., 1987; Trapp et al., 1988), primarily at the level of gene transcription (Lemke and Chao, 1988; Trapp et al., 1988).

The $\mathrm{P}_{0}$ promoter drove expression of the diphtheria toxin A chain gene (DT-A) to ablate myelinating Schwann cclls sclcctively (Messing et al., 1992), as DT-A is a potent inhibitor of protein synthesis (Pappenheimer, 1977). The DT-A cassette was inserted into a $\mathrm{P}_{0}$-hGH gene that had previously been shown to be selectively expressed in myelinating Schwann cells, such that DT-A would be the first open reading frame (Fig. 1). This line of mice produces a hypomyelinating defect (Messing et al., 1992).

The second line of transgenic mice has an SV 40 large T antigen tsA-1609 mutant gene after the $P_{0}$ promoter, such that the large $\mathrm{T}$ antigen gene would be the first open reading frame (see Fig. 1; Messing et al., 1994). This SV40 gene appears to trap developing Schwann cells in the proliferative phase, and the peripheral nerves contain Schwann cells that are unable to form myelin, resulting in a hypomyelinating phenotype (Messing et al., 1985; Small et al., 1986; Jensen et al., 1993).

Our data demonstrate that the hypomyelination of PNS axons in the two $\mathrm{P}_{0}$ transgenic lines of mice results in decreased NF phosphorylation, increased NF density, and decreased axonal diameter like the Trembler mouse, which is due to a defect in the peripheral myelin protein-22 (Suter et al., 1992).

\section{Materials and Methods}

Transgenic animals. Transgenic mice carrying $P_{0}$ diphtheria toxin or $P_{0}$ SV40 transgenes have been described previously (Messing et al., 1992, 1994). Breeding lines of animals are maintained in a hybrid C57BL/6 J $\times$ SJL background. The genetic designation for the lines of mice used in this study are $\mathrm{Tg}(\mathrm{Mpz}, \mathrm{SV} 40 \mathrm{E}) \mathrm{Bri} 135$ for the $\mathrm{P}_{0}$ SV40 transgene and $\operatorname{Tg}(\mathrm{Mpz}, \mathrm{DT}-\mathrm{A})$ Bri 167 for the $\mathrm{P}_{0}$ diphtheria toxin transgene. The mouse colony is maintained in an AAALAC accredited animal facility at the University of Wisconsin-Madison.

Electrophoresis. The whole sciatic nerve was suspended in SUB buffer $(0.5 \%$ SDS, $8 \mathrm{~m}$ urea, and $2 \% \beta$-mercaptoethanol) as described by de Waegh and Brady (1990). Electrophoresis was performed on 0.75-mmthick $6 \%$ polyacrylamide gels by SDS-polyacrylamide gel electrophoresis (SDS-PAGE). Each lane was loaded with approximately $10 \mu \mathrm{g}$ of protein from control and transgenic mouse sciatic nerves, and, as close as possible, equal amounts of NF-L were loaded in each lane on the gel. Then

\section{Diphtheria Toxin Transgene}

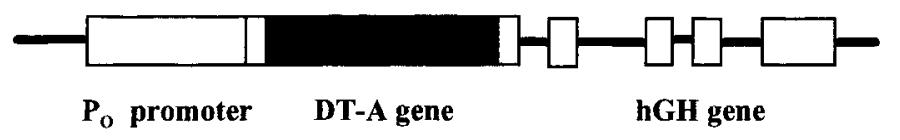

SV 40 Large $T$ antigen Transgene

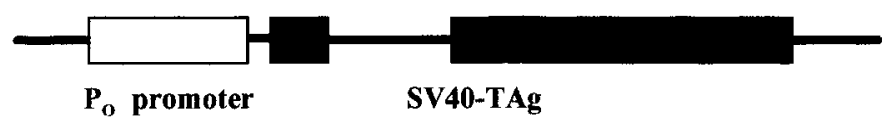

Figure 1. Transgenes. Schematic diagrams of the $\mathrm{P}_{0}-\mathrm{DT}-\mathrm{A}-\mathrm{hGh}$ and $P_{0}$-SV40-tsA-1609 cassettes used to generate transgenic mice. A $1.1 \mathrm{~kb}$ section of the rat $P_{0}$ promoter was subcloned upstream of these modules to direct expression exclusively to myelinating Schwann cells. DT-A sequences are inserted into the first exon of the hGH gene such that the DT-A open reading frame is translated (Messing ct al., 1992). The SV40 tsA-1609 mutant gene was attached downstream of the $P_{0}$ promoter (Messing et al., 1994).

the relative levels of NF-M and NF-H phosphoisoforms were normalized to that of NF-L as determined by quantitative immunoblots. Four transgenic mice from each line (eight nerves) along with four age-matched controls from each line were used for biochemical analysis.

Quantitative immunoblots. Following electrophoresis, proteins were transferred to nitrocellulose and probed with monoclonal antibodies (MAbs) that recognizc phosphorylation-dependent $(\mathrm{P}+, \mathrm{P}++, \mathrm{P}+++)$ or dephosphorylation-dependent (dP) epitopes, as described by Lee et al. (1987, 1988a,b). Phosphorylation-independent MAbs that reacted with NF-H, NF-M, or NF-L epitopes regardless of phosphorylation state were used to quantitate total NF proteins on immunoblots of control and transgenic mice samples. All of the antibodies used here are summarized in Table 3 and have been characterized earlier (Carden et al., 1987; Lee et al., 1987, 1988a,b). To quantitate NF protein levels, the blots were washed five times for $3 \mathrm{~min}$ in GB buffer ( $50 \mathrm{~mm}$ triethanolamine, $0.5 \%$ Triton X-100, $0.1 \mathrm{M} \mathrm{NaCl}, 2 \mathrm{~mm}$ K-EDTA, $0.1 \%$ SDS,

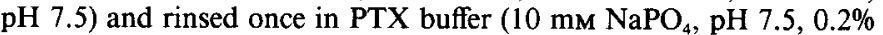
Triton X-100, $0.15 \mathrm{M} \mathrm{NaCl}, 1 \mathrm{~mm}$ EGTA). They were then incubated for $60 \mathrm{~min}$ in ${ }^{125}$ I-labeled goat anti-mouse $\mathrm{IgG}\left(2 \times 10^{6} \mathrm{dpm} / \mathrm{ml}\right)$ for the mouse MAbs, or protein A $\left(2 \times 10^{6} \mathrm{dpm} / \mathrm{ml}\right)$ for the rabbit polyclonal antibodies in 4\% BSA-PTX, and finally washed five times for 3 min in GB buffer (Earnshaw et al., 1987).

Blots were then exposed to a phosphor screen for 5-24 hr and the amount of radioactivity for each protein band was quantified on a Phosphor Imager (Molecular Dynamics). The amount of radioactivity was expressed as a ratio of NF-H or NF-M isoforms to NF-L in the same lane. The degree of phosphorylation was then compared between transgenic and control samples on the same blot.

Electron microscopy. Sciatic nerves were examined by electron microscopy as described by de Waegh et al. (1992). Animals were killed with $\mathrm{CO}_{2}$, and their sciatic nerves were exposed and immediately im. mersed in situ in freshly prepared fixative containing $2 \%$ glutaraldehyde and $2 \%$ formaldehyde in cacodylate buffer. Following $15 \mathrm{~min}$ of initial fixation, nerves were removed and reimmersed in fresh fixative. The ncrves wcre stored in cacodylate buffer until they were analyzed. After three washes in fresh cacodylate buffer, each segment was dehydrated in a graded series of ethanols and embedded in Epon-Araldite resin. Ultrathin sections were stained for $1 \mathrm{~min}$ with uranyl acetate and $1 \mathrm{~min}$ in lead citrate, and examined in a Hitachi electron microscope. For the quantitative studies, the sciatic nerve was cut in cross section in the midthigh area and $8 \times 10$ inch photographs at a magnification of 60,000 were made of large-diameter axons cut in true cross section. In the electron microscopic analysis of the sciatic nerves, the use of the term "unmyelinated" refers to the large-diameter axons in the transgenic mice that do not have a myelin sheath. The small-diameter unmyelinated axons, grouped together with several axons ensheathed by one Schwann cell, were not used for the quantitative electron microscopic studies, 


\begin{tabular}{|c|c|}
\hline & $\begin{array}{l}\% \text { relative area in } \\
\text { sciatic nerve }\end{array}$ \\
\hline \multicolumn{2}{|l|}{ DT transgenic $(n=4)$} \\
\hline Myelinated & $34 \pm 3 \%$ \\
\hline Unmyelinated & $66 \pm 3 \%$ \\
\hline DT litter mate control $(n=4)$ & $100 \%$ \\
\hline \multicolumn{2}{|l|}{ SV40 transgenic $(n=4)$} \\
\hline Myelinated & $78 \pm 5 \%$ \\
\hline Unmyelinated & $22 \pm 5 \%$ \\
\hline SV40 litter mate control $(n=4)$ & $100 \%$ \\
\hline
\end{tabular}

although they were included in the biochemical analysis of the whole sciatic nerve. Axons with all of the NFs in true cross section represent approximately $5 \%$ of the axons in each cross section of the nerve. This representative sampling of axons was used for analysis that included the range of axonal calibers in each category (unmyelinated transgenic, myelinated transgenic, and myelinated control). We did not compare exactly equal sizc axons in cach category because of the smaller size of all of the axons in the transgenic mice. In any event, it was not necessary to compare axons of the same caliber in each category because the NF density did not vary in relation to the caliber of the axons (an ANOVA test of this data revealed no significant relationship between axon caliber and NF density). The NFs were counted using a template of hexagons, each of which enclosed an area of $2.6 \mathrm{~cm}^{2}(9 \mathrm{~mm}$ per side). All NFs were counted in every hexagon included within the axonal boundaries, as described earlier (de Waegh et al., 1992). We did not include any hexagons in the quantitative studies in which vesicular organelles occupied more than approximately $10 \%$ of the area of the hexagon or in which the NFs were not all in true cross section. Therefore, the densities reported are average densities per hexagonal area of axoplasm that was free of vesicular elements (Price et al., 1988). At this magnification, each hexagon represent a $5.8 \times 10^{-7} \mathrm{~m}^{\prime}$ rcgion of axoplasm. Nerves from four mice from each line of transgenic mice and their age-matched controls were analyzed. Over 60 large-diameter axons in true cross section were selected in sections of transgenic and control sciatic nerve segments from the midthigh region. Over 300 hexagons were counted for each transgenic and each control mouse, with over 2500 NFs each. The DT mice were $26-30 \mathrm{~d}$ old, and the SV 40 mice were all $20 \mathrm{~d}$ old.

The cross-sectional area of all individual large-diameter axons (i.e., those not grouped together and ensheathed by a single Schwann cell) was determined from $8 \times 10$ inch photographs at a magnification of $2000 \times$ from the same section of sciatic nerve. The length and width of each axon (not including the axon sheath) was measured and then the area was determined, using these measurements to approximate an oval (Tables 1,2). This cross-sectional area is used to compare the percentage of unmyelinated versus myelinated large-diameter axons in the sciatic nerves in Table 1. Cross-sectional area was used instead of the number of unmyelinated versus myelinated axons because the number does not reflect the true amount of NF protein involved with the smaller size of the unmyelinated axons.

Statistical analysis. Statistical analysis of the quantitative immunoblots, NF density, and cross-sectional area was done with the $t$ test on Microsoft EXCELL software. The variability in all of the data presented represents the standard error in the data from the $t$ test analysis. An ANOVA test on the cross-sectional area in Table 2 demonstrated that each category on the table had a statistically significant difference in mean of $p<0.005$ or better. An ANOVA test of the NF density demonstrated no statistical relationship between NF density and axonal caliber.
Table 2. Average cross-sectional area of large-diameter axons in sciatic nerves

\begin{tabular}{ll} 
& $\mu \mathrm{m}^{2}$ \\
\hline DT transgenic $(n=4)$ & $3.62 \pm 0.08$ \\
$\quad$ Myelinated & $2.42 \pm 0.04$ \\
Unmyelinated & $2.83 \pm 0.08$ \\
Transgenic (myelinated and unmyelinated) & $6.53 \pm 0.02$ \\
DT litter mate control $(n=4)$ & \\
SV40 transgenic $(n=4)$ & $3.04 \pm 0.02$ \\
Myelinated & $1.84 \pm 0.02$ \\
Unmyelinated & $2.77 \pm 0.02$ \\
Transgenic (myelinated and unmyelinated) & $4.59 \pm 0.05$ \\
SV40 litter mate control $(n=4)$ & \\
\hline
\end{tabular}

\section{Results}

\section{Electron microscopy and morphometry}

The percentage of myelinated axons versus unmyelinated axons, based on the cross-sectional area, in each line of transgenic mice demonstrated that the DT mice had much more extensive hypomyelination than the SV40 mice (Fig. 2, Table 1). Of the large-diameter axons, $66 \%$ of the cross-sectional area was unmyelinated in the DT mice versus only $22 \%$ of the area in the SV40 mice $(p<0.005$; Table 1$)$. This difference in the amount of hypomyelination correlates with the quantitative immunoblot data that demonstrates the reduction in NF phosphorylation (see below).

The density of NFs was greater in the unmyelinated largediameter axons in each line of transgenic mice when compared to myelinated axons in age-matched controls (Figs. 2, 3). The NF densities were determined in cross sections through internodal axons of sciatic nerve of age-matched control mice and each of the transgenic lines. Nodal and paranodal axonal regions as well as regions with Schmidt-Lanterman clefts were excluded from the analyses because NF densities are altered in normal axons in these areas. Unmyelinated axons from both lines of transgenic mice showed an increase in NF density compared to controls. Myelinated axons from both lines of transgenic mice also showed an increase in NF density compared to controls, but not as large as the unmyelinated axon (Fig. 4). This may be due to some disruption of normal myelination in all of the largediameter axons. NFs were randomly distributed throughout cross sections of transgenic and control mice and the frequency distribution of densities was consistent with those seen by Price et al. (1988). In the DT mice, the myelinated axons had $145.4 \pm$ $6.7 \mathrm{NFs} / \mu \mathrm{m}^{2}$ and the unmyelinated axons had $235.9 \pm 7.0 \mathrm{NFs} /$ $\mu \mathrm{m}^{2}$, while the controls had $90 \pm 2.4 \mathrm{NFs} / \mu \mathrm{m}^{2}(p<0.005$; Fig. $4 A, C, E)$. In the SV40 mice, the myelinated axons had 114.45 $+3.3 \mathrm{NFs} / \mu \mathrm{m}^{2}$ and the unmyelinated axons had $156.25 \pm 7.2$ $\mathrm{NFs} / \mu \mathrm{m}^{2}$, while the control axons had $93.9 \pm 2.5 \mathrm{NFs} / \mu \mathrm{m}^{2}(p$ $<0.005$; Fig. $4 B, D, F)$.

The average axonal cross-sectional area of axons in the sciatic nerves of transgenics and controls was determined, and this

Figure 2. Flectron micrographs of normal $(A, B)$, SV40 transgenic $(C, D)$, and DT transgenic $(E, F)$ sciatic nerves. $A, C$, and $E$ are transverse sections of sciatic nerve at $2000 \times$ magnification. $B, D$, and $F$ are longitudinal sections of sciatic nerve at $60,000 \times$ magnification. These axons are representative of the changes seen in either the myelinated control axons or the unmyelinated axons from the transgenic mice. They are not the same caliber because the unmyelinated axons from the transgenic mice are smaller. As stated in the Discussion, the density of NFs in each category did not vary significantly with axonal caliber. Arrowheads mark large-diameter axons that are unmyelinated. 

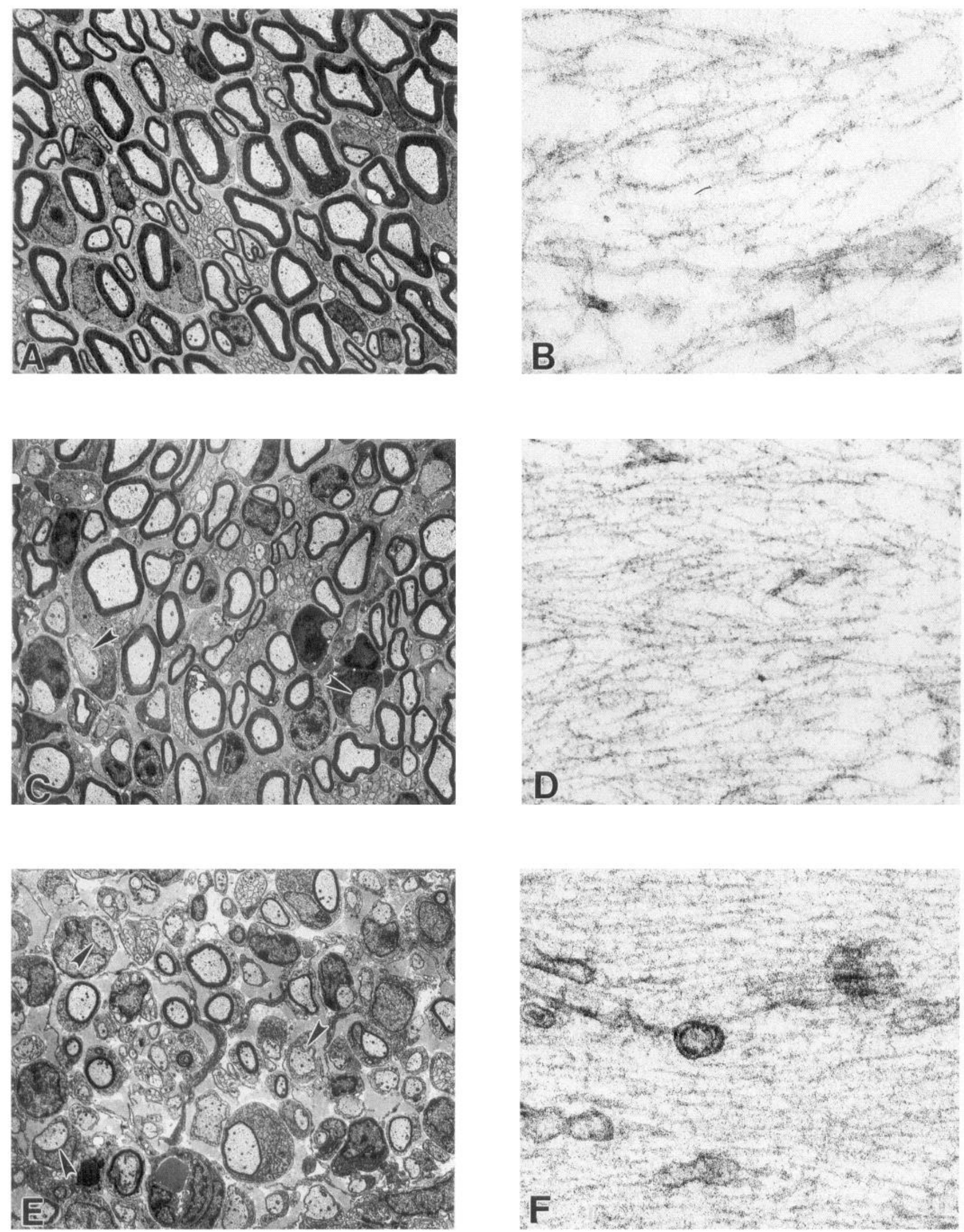

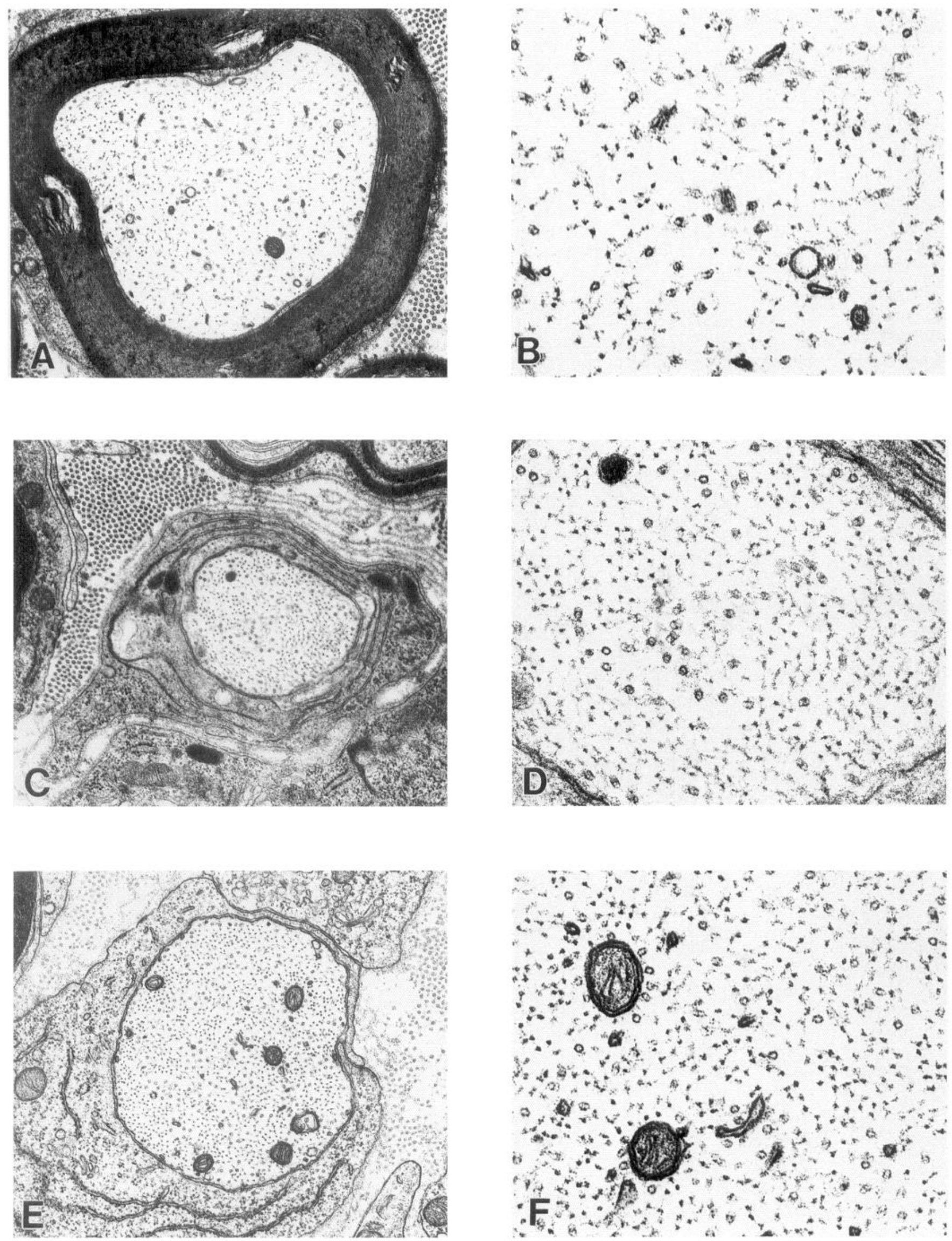
revealed that the average size of the large-diameter axons in the transgenic mice was smaller than the average of the control axons (Table 2). The axons in the DT transgenic mice showed a greater difference than those in the SV40 mice. In the DT mice the average size of the axon was $43 \%$ of the age-matched control axons, contrasted to $60 \%$ in the SV 40 micc (Table 2). There also was a difference between myelinated and unmyelinated axons within each line of mice. In the DT mice, the unmyelinated axons had the smallest average cross-sectional area $\left(2.42 \pm 0.04 \mu \mathrm{m}^{2}\right)$, the myelinated axons had larger areas (3.62 $\left.\pm 0.08 \mu \mathrm{m}^{2}\right)$, and the age-matched controls had the largest axonal area $\left(6.53 \pm 0.02 \mu \mathrm{m}^{2}, p<0.005\right.$; Table 2$)$. The SV40 mice showed a similar relationship; the unmyelinated axons were the smallest $\left(1.84 \pm 0.02 \mu \mathrm{m}^{2}\right)$, the myelinated axons were larger $\left(3.04 \pm 0.02 \mu \mathrm{m}^{2}\right)$, and the age-matched controls were the largest $\left(4.59 \pm 0.05 \mu \mathrm{m}^{2}, p<0.005\right.$; Table 2). Overall, the SV40 axons were smaller and this is probably due to the fact that these mice were younger ( $20 \mathrm{~d}$ old) than the DT mice (26$30 \mathrm{~d}$ old). It is interesting to note that the SV40 mice were phenotypically more affected (i.e., they showed more severe trembling) than the DT mice.

\section{Biochemical analysis}

Several anti-NF antibodies that distinguish between phosphorylated isoforms of NF proteins (Table 3 ) were used to determine biochemical differences between the transgenic and control sciatic nerves. MAbs that recognize the phosphorylation state of NF isoforms were used to determine the level of phosphorylation, while phosphorylation-independent antibodies were used to quantify total NF subunit proteins (Lee et al., 1987, 1988a,b; de Waegh et al., 1992).

For each antibody, six lanes of transgenic sciatic nerve were compared to six lanes of control sciatic nerve on the same gel. Approximately the same amount of NF-L for each of the samples was loaded and then the ratio of either NF-H or NF-M was compared to NF-L in the same lane (Fig. 5). A $t$ test was run on each gel to determine if there was a significant difference between the control and transgenic nerves. Figure 6 shows representative data produced with each antibody for both transgenic and control sciatic nerves, and a summary of the data for each antibody is shown in Figure 7. The largest difference in NF protein levels was seen with the antibody to dephosphorylated NF-H (RMdO9), which showed an increase of $90 \pm 32 \%$ in the DT mice and an increase of $27 \pm 9 \%(p<0.05)$ in the SV40 mice. The antibody to highly phosphorylated NF-H (RMO24) showed a decrease of $28 \pm 13 \%(p<0.05)$ in the DT mice, but no significant difference in the SV40 mice (Fig. 5). The antibodies to poorly phosphorylated NF-M (RMO108) and to phosphorylated NF-M (RMO55) showed a modest decrease in the DT mice, but it was not statistically significant. The SV40 mice showed similar statistically significant increases in RMdO9 binding, but no significant differences with most of the other antibodies, presumably because the level of hypomyelination was too low to cause a detectable change in the levels of the NF isoforms (Fig. 7).

\begin{tabular}{lll}
\hline $\begin{array}{l}\text { Table 3. Antibodies to NFs raised against rat epitopes that have } \\
\text { been previously characterized }\end{array}$ & $\begin{array}{l}\text { Phosphorylation } \\
\text { state recognized }\end{array}$ \\
Subunit & P $++(6)$ & Antibody name \\
\hline NF-H & P $+(2)$ & RMO24 \\
& dP (0) & Ta51 \\
& Pind & RMdO9 \\
& P ++ & Polyclonal \\
NF-M & Pind (core) & RMO55 \\
& poorly phosphorylated & RMO189 \\
& Pind & RMO108 \\
NF-L & Polyclonal
\end{tabular}

$\mathrm{P}+, \mathrm{P}++$, and $\mathrm{P}+++$ recognize epitopes corresponding to increasing levels of phosphorylation at the multiple phosphorylation domain. For NF-H, P+, and $\mathrm{P}+++$, antibodies bind to epitopes corresponding to two and six consecutive phosphorylated repeats, respectively, within the multiphosphorylation domain. dP recognizes NF-H when six consecutive repeats within the multiphosphorylation repeats are not phosphorylated. Pind recognizes epitopes distinct from the multiphosphorylation domain and binds to a specific NF subunit independently of the level of phosphorylation. All antibodies have been previously characterized and were shown to be specific for different levels of phosphorylation of a given NF subunit (Lee et al., 1987, 1988a,b).

Finally, the amount of NF-H, NF-M, and NF-L detected with phosphate-independent antibodies did not appear to vary between the control and transgenic sciatic nerves, which implies that the dorsal root ganglia neurons synthesize and transport similar amounts of NF proteins despite the hypomyelination of the transgenic sciatic nerves.

\section{Discussion}

Although mechanisms that regulate axon caliber have not been elucidated, several factors have been correlated with axon caliber including number of NFs, target size, and the thickness of the myelin sheath (Friede and Samorajski, 1970). NF density varies between axons in different white matter tracts (Szaro et al., 1990), and even along a single axon (Berthold, 1982; Price et al., 1988), implying that local regulation of axon cytoskeletal organization must occur. Since cytoskeletal elements undergo a variety of posttranslational modifications, these may regulate cytoskeletal dynamics and organization as well as axon caliber.

Previously, changes in hypomyelinated axons have been studied in the Trembler mouse, in which the hypomyelination is produced by a defect in the peripheral myelin protein-22 (Suter et al., 1992). These studies showed a reduction of axonal diameter (Aguayo et al., 1977; Pollard and McLeod, 1980; Perkins et al., 1981), altered slow axonal transport, altered regeneration of the axons (de Waegh and Brady, 1990), decreased NF phosphorylation, and increased NF density (de Waegh et al., 1992) in the hypomyelinated regions.

Because the hypomyelination produced in the two lines of transgenic mice studied here have resulted from two different mechanisms distinct from those in the Trembler mice, the results of this study give strong support to the hypothesis that the Schwann cell has a significant influence on the phosphorylation

Figure 3. Neurofilament density in the axons of the sciatic nerve in control, SV40 transgenic, and DT transgenic mice. $A$ and $B$, Age-matched myelinated control axons. $C$ and $D$, Unmyelinated SV40 transgenic axons; and $E$ and $F$, Unmyelinated DT transgenic axons. $A$, $C$, and $E$ each contain an entire axon in the sciatic nerve shown in transverse section to demonstrate the distribution of NFs through the entire axon (30,000 $\times$ magnification). $B, D$, and $F$ illustrate NF density of control and transgenic axons $(60,000 \times$ magnification). This is the magnification at which the $\mathrm{NF}$ counts were done to determine density. 
A

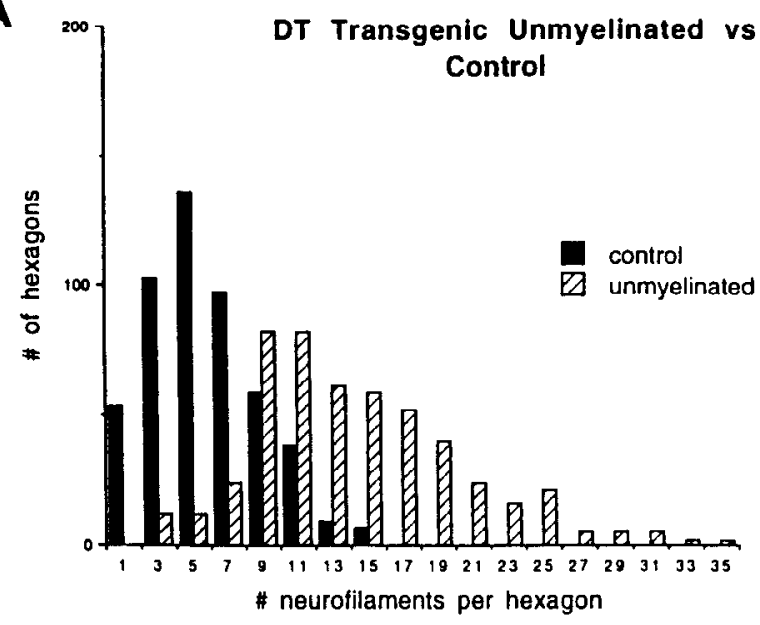

B

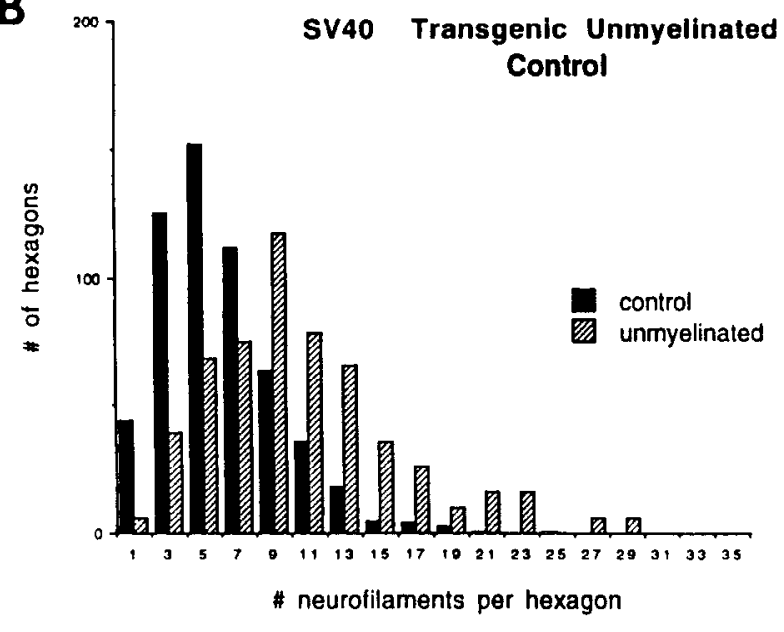

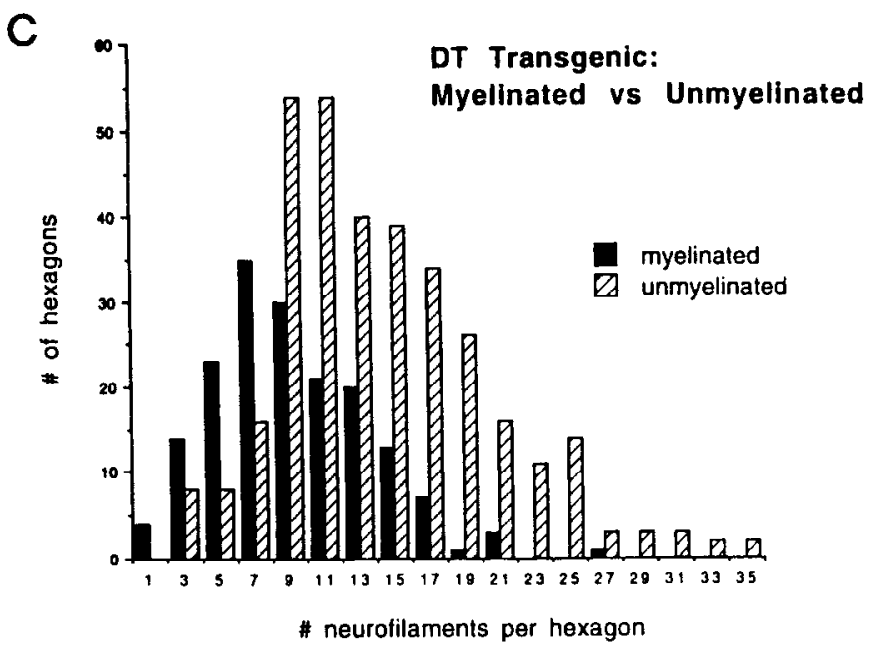

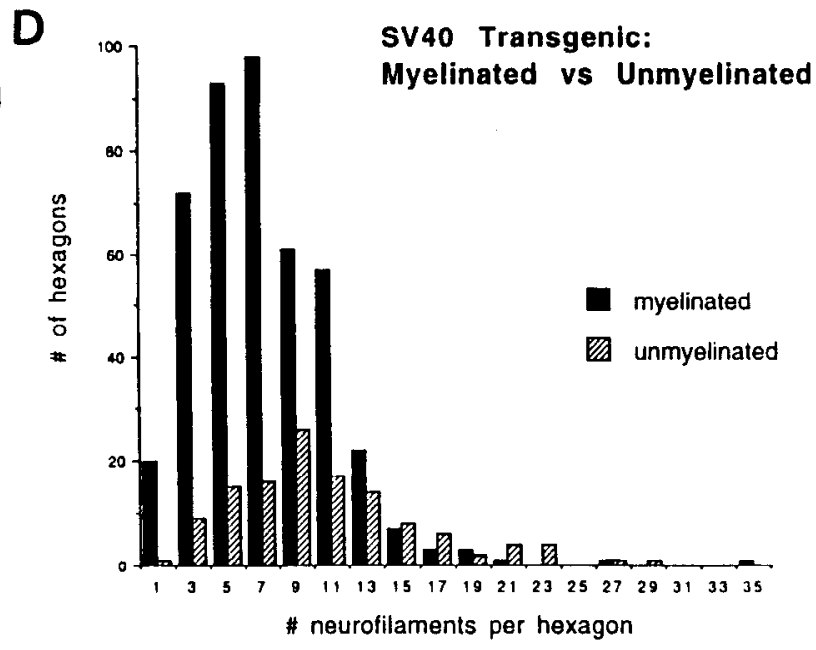

$\mathbf{E}$

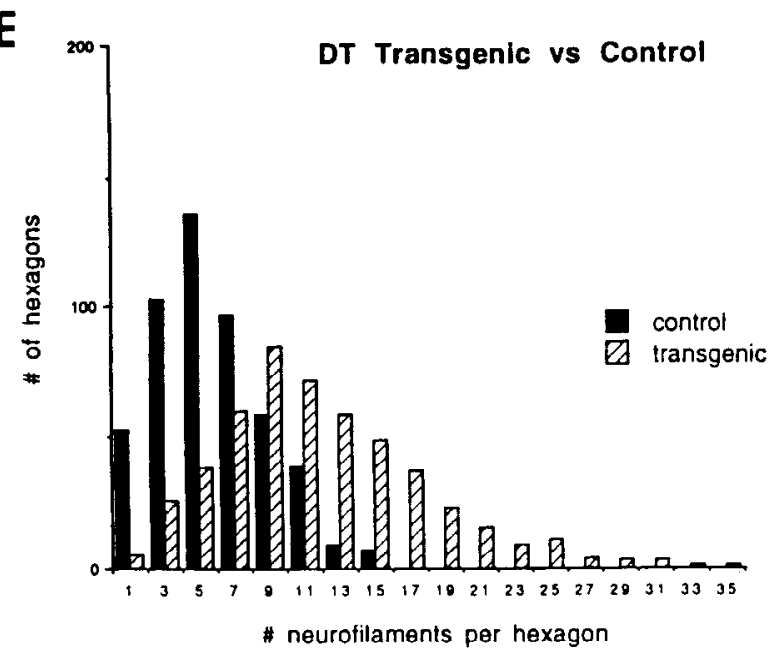

Figure 4. Neurofilament density distribution in sciatic nerve axons. $A, C$, and $E$ compare NF densities in DT transgenic mice. $B, D$, and $F$ compare NF densities in SV40 transgenic mice. A, Comparison of NF density in the axons of control versus unmyelinated DT transgenic. The average number of NFs/hexagon was $5.3 \pm 0.14$ in control and $14.3 \pm 0.41$ in unmyelinated axons in DT transgenic. This correlates to $90 \pm 2.4$ $\mathrm{NFs} / \mu \mathrm{m}^{2}$ and $235.9 \pm 7.0 \mathrm{NFs} / \mu \mathrm{m}^{2}$, respectively. These numbers represent a greater than twofold increase in NF density. $C$, Comparison of NF density in the axons of myelinated versus unmyelinated DT transgenic. The average number of NFs/hexagon was $8.6 \pm 0.40$ in myelinated and $14.3 \pm 0.41$ in unmyelinated axons in DT transgenic. This correlates to $145.4 \pm 6.7 \mathrm{NFs} / \mu \mathrm{m}^{2}$ and $235.9 \pm 7.0 \mathrm{NFs} / \mu \mathrm{m}^{2}$, respectively. This represents approximately a 1.6 -fold increase in NF density even between myelinated and unmyelinated large-diameter axons in the same nerve. $E$, Comparison of NF density in the axons of control versus all of the axons (myelinated and unmyelinated) in the DT transgenic. The average 


\section{Control}

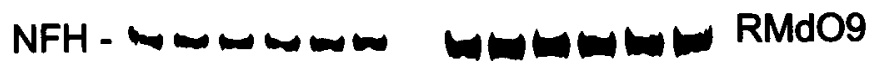

NFM -
RMO 108

A

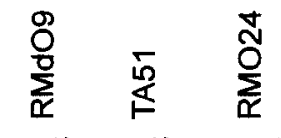

$\vdash 0 \vdash 0 \vdash 0$

NFH $-\omega \infty m \infty$

NFM -

\section{NFL - - - - - $-\infty-\infty-\infty$ anti NFL}

Figure 5. Immunoblot analysis of NF phosphorylation state in transgenic and control sciatic nerves. A representative immunoblot of a $6 \%$ SDS-PAGE gel of control and transgenic sciatic nerves labeled with RMd09 (NF-H, dP), RMO 108 (NF-M, P+), and a rabbit polyclonal antibody to NF-L (Pind). Ten micrograms of total protein was loaded in each lane. Six lanes from one control nerve and six lanes from one DT transgenic nerve were loaded on one gel, to eliminate variation in loading and quantitation. NF-L was loaded as equally as possible for each sample. A ratio of either NF-H or NF-M to NF-L, was used for comparison to eliminate any variability in loading each lane.

of axonal NFs. As proposed by de Waegh et al. (1992), there may be transmembrane signals that modulate the balance between kinase and phosphatase activities in axons, changing phosphorylation levels for NF and possibly for other neuronal proteins, and this transmembrane signal from the Schwann cell may depend on normal myelin formation. Thus, when myelination is disturbed (i.e., by diphtheria toxin-induced lysis of Schwann cells, SV40 large T antigen disruption of normal growth of the Schwann cells, or by a natural mutation in the peripheral myelin protein-22 in Trembler mice), the axon does not receive the signal to phosphorylate the NF sidearms. However, the precise nature of this signaling pathway has not been determined.

A correlation was seen between the degree of perturbation of normal myelination and the increased density of NFs. NF densities increase significantly (Figs. 3,4 ) in the transgenic mouse axons versus the age-matched controls in both lines of transgenic mice. This increased density of NFs was greater in the DT mice compared to the SV40 mice. In DT mice, the unmyelinated transgenic axons showed a 2.6-fold increase in NF density compared to controls. In SV40 mice, the difference was only a 1.7fold increase in NF density (Fig. 4). This larger difference in densities correlates with the more significant disruption in myelination that is seen in the DT mice. This difference is also seen when all of the axons, myelinated and unmyelinated, in the transgenics are compared to the control mouse axons. It

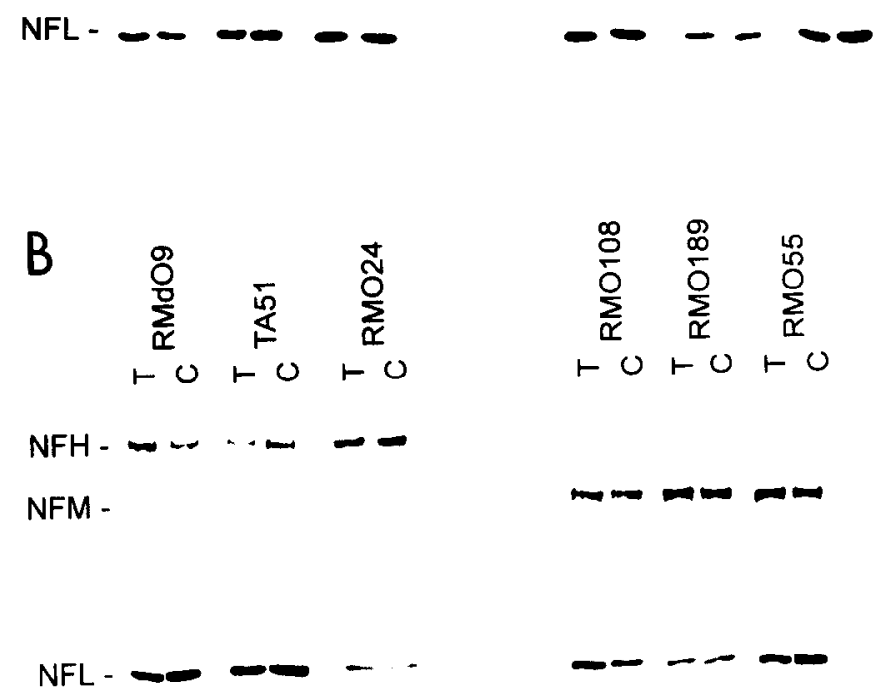

Figure 6. Composite of immunoblot analysis for each of the antibodies used to determine the phosphorylation state of NF-H and NF-M in transgenic and control sciatic nerves. Immunoblots of 6\% SDS-PAGE gels of sciatic nerves from transgenic mice $(T)$ and control $(C)$. RMdO9 (NF-H, dP), Ta51 (NF-H, P+ +), RMO24 (NF-H, P+++), RMO189 (NF-M, Pind), RMOl08 (NF-M, P+), RMO55 (NF-M, P++), and rabbit anti-NF-L (Pind) were used to probe the blots. $A$, Immunoblots for DT transgenic mice. Although not obvious by visual inspection of the blots, the statistical analysis revealed that TA51 $(\mathrm{NF}-\mathrm{H} \mathrm{P}+)$ and RMO24 (NF-H P +++ ) reactivities are greater in control nerves than in transgenic nerves. This suggests a decrease in NF phosphorylation in the transgenic. $B$, Immunoblots for SV40 transgenic mice, using the same antibodies as $A$.

appears that the more the Schwann cell's normal myelination is perturbed the more this affects NF density.

For the NF density to increase $90 \%$ in the DT mice and $27 \%$ in the SV40 mice relative to normal axons, changes must occur in interactions between NFs and other structures in the axon. The NF sidearms formed by NF-M and NF-H carboxy termi-

\footnotetext{
number of NFs/hexagon was $5.3 \pm 0.14$ in control and $12.1 \pm 0.32$ in the in DT transgenic mice. This correlates to $90 \pm 2.4 \mathrm{NFs} / \mu \mathrm{m}^{2}$ and 202.1 $\pm 5.5 \mathrm{NFs} / \mu \mathrm{m}^{2}$, respectively. These numbers also show a greater than twofold increase in NF density when both myelinated and unmyelinated axons are compared to the age-matched control axons. This represents the entire nerve that is used for the biochemical analysis for NF phosphorylation. $B$, Comparison of NF density in the axons of control versus unmyelinated SV40 transgenic. The average number of NFs/hexagon was $5.5 \pm 0.15$ in control and $9.1 \pm 0.42$ in unmyelinated axons in SV40 transgenic. This correlates to $93.9 \pm 2.5 \mathrm{NFs} / \mu \mathrm{m}^{2}$ and $156.2 \pm 7.2 \mathrm{NFs} /$ $\mu \mathrm{m}^{2}$, respectively. These numbers represent a 1.7 -fold increase in NF density. $D$, Comparison of NF density in the axons of myelinated versus unmyelinated SV40 transgenic. The average number of NFs/hexagon was $6.7 \pm 0.19$ in myelinated and $9.1 \pm 0.42$ in unmyelinated axons in SV40 transgenic. This correlates to $114.5 \pm 3.3 \mathrm{NFs} / \mu \mathrm{m}^{2}$ and $156.2 \pm 7.2 \mathrm{NFs} / \mu \mathrm{m}^{2}$, respectively. This represents approximately a $1.4-$ fold increase in NF density. $F$, Comparison of NF density in the axons of control versus all of the axons (myelinated and unmyelinated) in the SV40 transgenic. The average number of NFs/hexagon was $5.5 \pm 0.15$ in control and $7.4 \pm 0.19$ in the in SV40 transgenic mice. This correlates to $93.9 \pm 2.5 \mathrm{NFs} /$ $\mu \mathrm{m}^{2}$ and $126.6 \pm 3.3 \mathrm{NFs} / \mu \mathrm{m}^{2}$, respectively. These numbers represent a 1.3 -fold increase in NF density in the entire nerve. This smaller increase is reflected in the changes that are seen in the biochemical analysis for NF phosphorylation.
} 
A Quantitative Immunoblot Analysis of the Difference in NF Antibody Reactivity in Diphtheria Toxin Transgenic vs Control Sciatic Nerves

Figure 7. Quantitative immunoblot analysis of the difference in NF antibody reactivity of four transgenic versus four control sciatic nerves. Relative transgenic reactivities are measured by calculating the ratio of radioactivity bound to nitrocellulose blots of sciatic nerves from transgenic over the radioactivity incorporated in control. An asterisk indicates that the data obtained from each blot of transgenic versus control was statistically significant. $A$, Comparison of antibody reactivity in the DT transgenic mice. RMdO9, which labels the dephosphorylated epitopes of NF-H, was increased $90 \pm 32 \%$ in the transgenic versus control. The phosphorylated epitopes of NF-H were decreased. TA51 (P+) showed a decrease of $15 \pm 22 \%$ and $\mathrm{RMO} 24(\mathrm{P}+++)$ showed a decrease of $28 \pm 13 \%$. The antibody to poorly phosphorylated NF-M (RMO108) showed a tendency to increase and the phosphorylated NF-M (RMO55) showed a tendency to decrease but the data was not statistically significant. The rabbit polyclonal anti-NF-H and RMO189, which labels the core of NF-M, are both phosphorylation independent and showed no change between transgenic and control. $B$, Comparison of antibody reactivity in the SV40 transgenic mice. RMdO9, which labels the dephosphorylated epitopes of NF-H, was increased $27 \pm 9 \%$ in the transgenic versus control. TA51 $(\mathrm{P}+)$ showed a tendency to decrease but was not statistically significant. The remainder of the antibodies tested showed no significant difference. With the low percentage of unmyelinated large-diameter axons, it was not expected to detect a significant difference with many of the antibodies that show differences in the phosphorylation state of NFs.

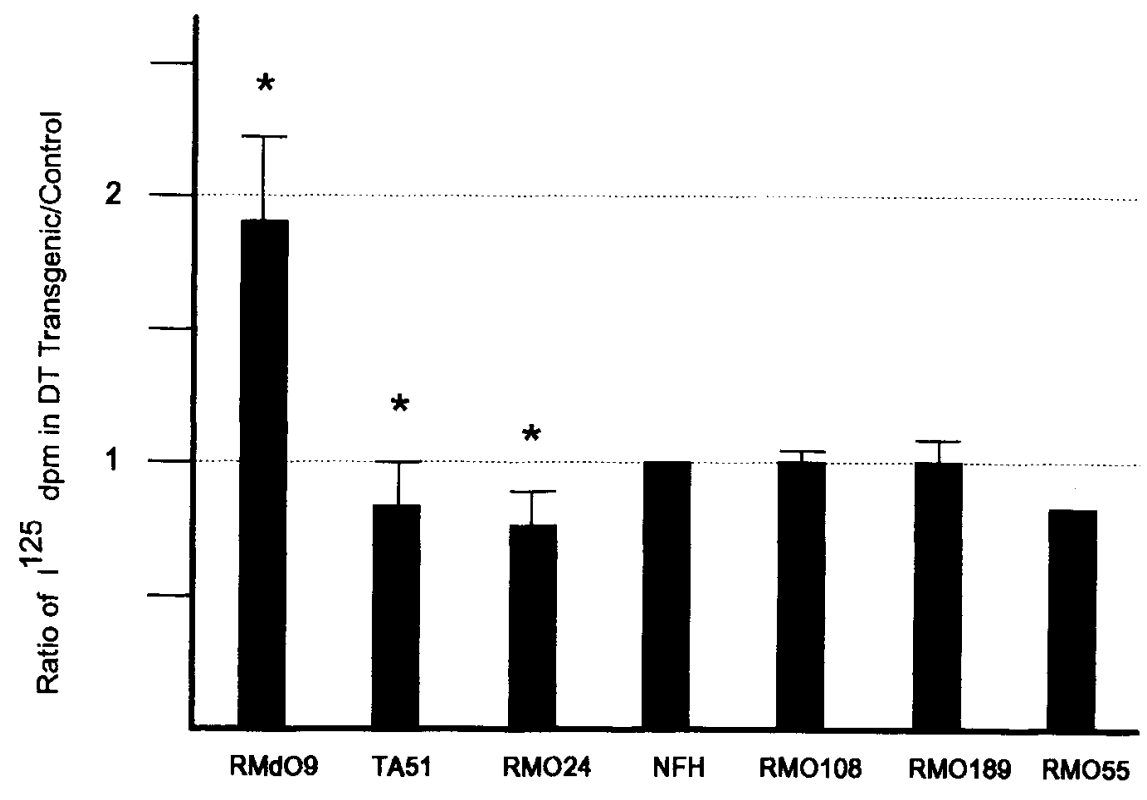

B Quantitative Immunoblot Analysis of the Difference in NF Antibody Reactivity in SV40 Transgenic vs Control Sciatic Nerves

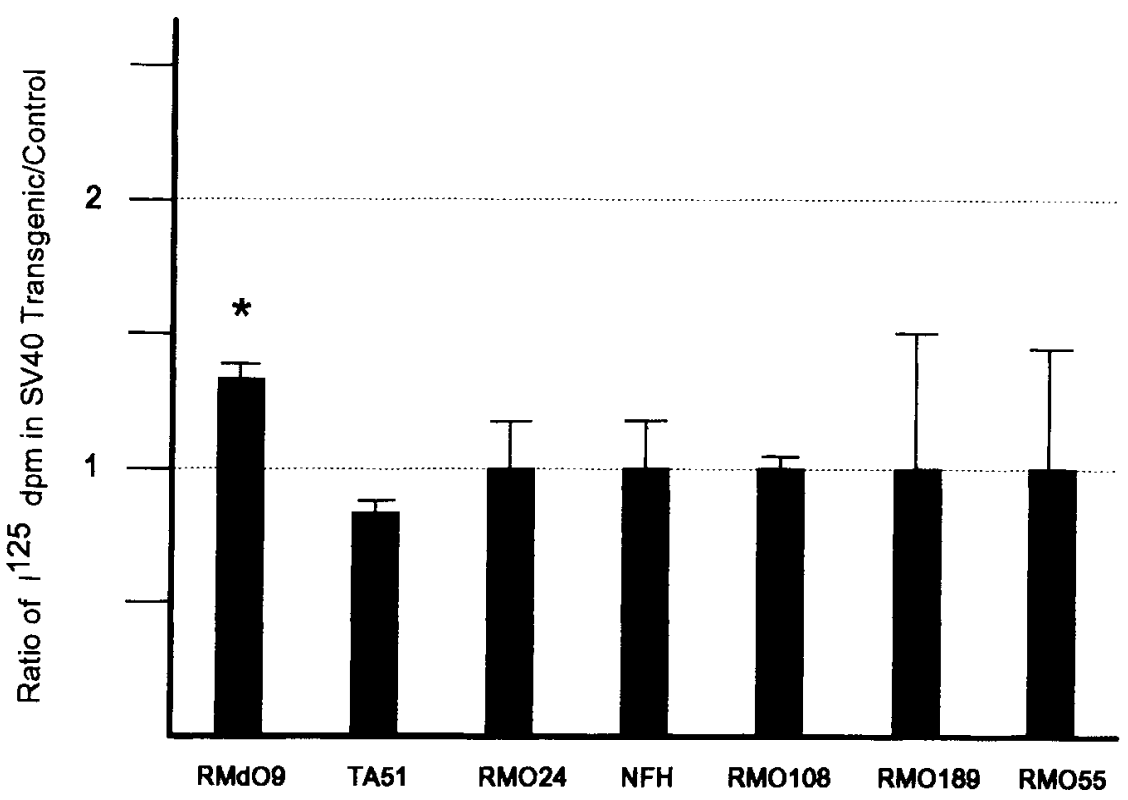

nals are believed to play a major functional role in determining surface properties of NFs. The NF carboxy-terminal sidearms project at regular $22 \mathrm{~nm}$ intervals along the filament. They contain highly conserved phosphorylation sites of NFs with multiple repeats of KSP sequences (Breen et al., 1988; Lee et al., $1988 \mathrm{a}, \mathrm{b})$. NF phosphorylation at these sites is currently believed to control how closely the NFs can pack together in the axon (de Waegh et al., 1992). Recently, antibodies specific for phosphorylated epitopes on NF-H and NF-M demonstrated a re- duction in the amount of phosphorylation at the node of Ranvier (Mata et al., 1992). When the KSP sites are phosphorylated, a large number of negative charges are added to the carboxylterminal regions of NF-M and NF-H, which is speculated to cause the sidearms to extend away from the main coiled-coil region of the filament. These negatively charged extensions will then prevent the NFs from moving close together, which decreases their density in the axon (Carden et al., 1987b).

A correlation was also seen between the degree of hypomye- 
lination and the dephosphorylation of the NFs. The degree of phosphorylation of NFs in these mice was compared with MAbs that are specific for different NF phosphorylation states (Table 3). For example, the RMdO9 antibody binds the repeated KSPAEA sequence on NF-H only when the serines in six consecutive tandem repeats are not phosphorylated (Clark and Lee, 1991), and this MAb showed a direct correlation to the observations obtained in the FM morphometry studies of the NFs. Specifically, RMdO9 showed the largest increase in labeling in the DT transgenic mice over the control. The labeling was also significantly increased in the SV40 mice, but the increase was not as large. This is the only MAb that showed a significant change in the SV40 mice. This is probably due to the very low level of hypomyelination (only $22 \%$ of the cross-sectional area of the large-diameter axons are unmyelinated) observed in these mice. The RMO24 MAb, which binds the same sequence as RMd09 only when six consecutive tandem repeats of this motif are phosphorylated (Clark and Lee, 1991), was significantly decreased in the DT mice (Fig. 6). These results support the current hypothesis that NF phosphorylation controls spacing. Further, the change in the NF phosphorylation and NF density in the axons in turn leads to a morphologic change in the size of the transgenic axons. The average size of the large-diameter axons in the transgenic mice was smaller than the average of the agematched control axons (Table 2). This demonstrates a correlation between the degree of hypomyelination, NF dephosphorylation, and decrease in axonal size. Also, for each transgenic line the unmyelinated axons are smaller than the myelinated axons in the sciatic nerve. This also correlates with the NF density, which is higher in the unmyelinated versus the myelinated axons in each transgenic line (Table 2).

This study indicated that NF synthesis is independent of myelination, since NF content appears to be unchanged. The total amount of NF-H, NF-M, and NF-L did not appear to be changed in the transgenic mice compared to the control mice (Figs. 6, 7). Thus, the mechanisms that determine the amount of NF protein in the axons do not seem to be regulated by Schwann cells. The control of axonal diameter is believed to be dependent on a variety of factors, including synthesis of proteins in the cell body, presence of growth factors, the neuron's developmental program, as well as factors that affect the density and distribution of microtubules and NFs in the axon (Friede and Samorajski, 1970). The developmental program of neurons and the synthesis of NF proteins did not seem to be affected in these two lines of transgenic mice.

Control of cellular mechanisms by phosphorylation or dephosphorylation of proteins is used extensively in eukaryotic cells. Alterations in NF phosphorylation may be important in normal nerves and pathologic events in nerves (Nixon, 1993). Indeed, NF phosphorylation has been shown to be important for regulating axonal transport and increasing the stability of NFs in neuronal processes (Griffin et al., 1988; Lewis and Nixon, 1988). Alterations in NF protein phosphorylation also have been documented in regenerating axons and in various ncuropathies. For example, increases in NF density can be seen in diabetic neuropathy (Medori et al., 1988a,b), which suggests that the increased NF density may result from altered patterns of NF phosphorylation. Heavily phosphorylated NF epitopes are found in Alzheimer's tangles (Lee et al., 1988b) and Lewy bodies in Parkinson's disease (Hill et al., 1991; Trojanowski et al., 1993). Some neurotoxic substances induce abnormal accumulations and increased NF phosphorylation (Bizzi and
Gambetti, 1986; Carden et al., 1986, 1987a; Johnson and Jope, 1988). It is unclear if the accumulation of NFs is a cause or a consequence of changes in NF phosphorylation, but recent studies showed that the overexpression of NF-H or NF-L in transgenic mice triggers neurodegenerative processes (Cote et al., 1993; Xu ct al., 1993).

Insights into the mechanisms whereby glial cells modulate axonal properties normally and in disease states are beginning to emerge and we anticipate that the transgenic mice described here will be important model systems for further studies of these mechanisms.

\section{References}

Aguayo AJ, Attiwell M, Trecarten J, Perkins S, Bray GM (1977) Abnormal myelination in transplanted Trembler mouse Schwann cells. Nature 265:73-74.

Berthold C (1982) Some aspects of the ultrastructural organization of peripheral myelinated axons in the cat. In: Axoplasmic transport (Weiss D, ed), pp 40-54. New York: Springer.

Bizzi A, Gambetti P (1986) Phosphorylation of neurofilaments is altered in aluminum intoxication. Acta Neuropathol (Berl) 71:154-158.

Bray GM, Rasminsky M, Aguayo AJ (1981) Interactions between axons and their sheath cells. Annu Rev Neurosci 4:127-162.

Breen K, Robinson P, Wion D, Anderton B (1988) Partial sequence of the rat heavy neurofilament polypeptide (NFH): identification of putative phosphorylation sequences. FEBS Lett 241:213-218.

Brockes JP, Raff MC, Nishiguchi DJ, Winter J (1980) Studies on cultured rat Schwann cells. III. Assays for peripheral myelin proteins. J Neurocytol 9:67-77.

Carden MJ, Eagles PAM (1983) Neurofilaments from ox spinal nerves. Isolation, disassembly, reassembly and cross-linking properties. Biochem J 215:227-237.

Carden MJ, Lee VM-Y, Schlaepfer WW (1986) 2,5-Hexanedione neuropathy is associated with covalent crosslinking of neurofilament proteins. Neurochem Pathol 5:15-35.

Carden MJ, Goldstein M, Bruce J, Cooper H, Schlaepfer W (1987a) Studies of neurofilaments that accumulate in proximal axons of rat intoxicated with $B, B$-iminodiproprionitrile (IDPN). Neurochem Pathol 7:189-205

Carden MJ, Trojanowski JQ, Schlaepfer WW, Lee VM-Y (1987b) Two stage expression of neurofilament polypeptides during rat neurogenesis with early establishment of adult phosphorylation patterns. J Neurosci 7:3489-3504.

Clark EA, Lee VM-Y (1991) Dynamics of mammalian high-molecular-weight neurofilament subunit phosphorylation in cultured rat sympathetic neurons. J Neurosci Res 30:116-123.

Cote F, Collard J-F, Julien J-P (1993) Progressive neuronopathy in transgenic mice expressing the human neurofilament heavy gene: a mouse model of amyotrophic lateral sclerosis. Cell 73:35-46.

de Waegh S, Brady ST (1990) Altered slow axonal transport and regeneration in a myelin-deficient mutant mouse: the Trembler as an in vivo model for Schwann cell-axon interactions. J Neurosci 10: $1855-1865$.

de Waegh S, Lee VM-Y, Brady ST (1992) Local modulation of neurofilament phosphorylation, axonal caliber, and slow axonal transport by myelinating Schwann cells. Cell $68: 451-463$.

Earnshaw WC, Sullivan KF, Machlin PS, Cooke CA, Kaiser DA, Pollard TD, Rothfield NF, Cleveland DW (1987) Molecular cloning of cDNA for CENP-B, the major human centromere autoantigen. J Cell Biol 104:817-829.

Fraher JP (1978) Quantitative studies on the maturation of central and peripheral parts of individual ventral motorneuron axons: I. Myelin sheath and axon caliber. J Anat 126:509-533.

Friede RL, Samorajski T (1970) Axon caliber related to neurofilament and microtubules in sciatic nerve fibers of rats and mice. Anat Rec 167:379-388.

Griffin J, Rosenfeld J, Hoffman P, Bold B, Trapp B (1988) The axonal cytoskeleton influences on nerve fiber form and Schwann cell behavior. In: Intrinsic determinants of neuronal form and function (Lasek RJ, Black MM, eds), pp 403-439. New York: Liss.

Hill WD, Lee VM-Y, Hurtig HI, Murray JM, Trojanowski JQ (1991) Epitopes located in spatially separate domains of each neurofilament 
subunit are present in Parkinson's disease Lewy bodies. J Comp Neurol 309:150-160.

Hirokawa N, Glicksman M, Willard M (1984) Organization of mammalian neurofilament polypeptides within the neuronal cytoskeleton. J Cell Biol 98:1523-1536.

Hisanaga S, Hirokawa N (1988) Structure of the peripheral domains of neurofilaments revealed by low angle rotary shadowing. J Mol Biol 202:297-305.

Hoffman P, Thompson G, Griffin J, Price D (1985) Changes in neurofilament transport coincide temporally with alterations in the caliber of axons in regenerating motor fibers. J Cell Biol 101:1332-1340.

Jensen NA, Smith GM, Shine HD, Garvey JS, Hood L (1993) Distinct hypomyelinated phenotypes in MBP-SV40 large T transgenic mice. J Neurosci Res 34:257-264.

Johnson G, Jope R (1988) Phosphorylation of rat brain cytoskeletal proteins is increased after orally administered aluminum. Brain Res 456:95-103.

Julien J-P, Mushynski WE (1983) The distribution of phosphorylation sites among identified proteolytic fragments of mammalian neurofilaments. J Biol Chem 258:4019-4025.

Julien J-P, Mcijer D, Hurst J, Grosveld F (1986) Cloning and developmental expression of the murine neurofilament gene family. Mol Brain Res 1:243-250.

Lasek RJ, Oblinger M, Drake P (1983) Molecular biology of neuronal geometry: expression of neurofilament genes influences axonal diameter. Cold Spring Harbor Symp Quant Biol 18:731-744.

LeBlanc AC, Poduslo JF, Mezei C (1987) Gene expression in the presence or absence of myelin assembly. Brain Res 388:57-67.

Lee VM-Y, Carden M, Schlaepfer W, Trojanowski J (1987) Monoclonal antibodies distinguish several differentially phosphorylated states of the two largest rat neurofilament subunits (NFH and NFM) and demonstrate their existence in the normal nervous system of adult rats. J Neurosci 7:3474-3488.

Lee VM-Y, Otvos L, Carden M, Hollosi M, Dietzschold B, Lazzarini $R$ (1988a) Identification of the major multiphosphorylation site in mammalian neurofilaments. Proc Natl Acad Sci USA 85:1998-2002.

Lee VM-Y, Otvos L, Schmidt MS, Trojanowski J (1988b) Alzheimer's disease tangles share immunological similarities with multiphosphorylation repeats in the two large neurofilament proteins. Proc Natl Acad Sci USA 85:7384-7388.

Lemke G, Chao M (1988) Axons regulate Schwann cell expression of the major myelin and NGF receptor genes. Development 102:499_ 504.

Levy E, Liem RKH, D'Eustachio P, Cowan NJ (1987) Structure and evolutionary origin of the gene encoding mouse NF-M, the middlemolecular-mass neurofilament protein. Eur J Biochem 166:71-77.

Lewis SA, Cowan NJ (1986) Anomalous placement of introns in a member of the intermediate filament multigene family: an evolutionary conundrum. Mol Cell Biol 6:1529-1534.

Lewis S, Nixon R (1988) Multiple phosphorylated variant of high molecular mass subunit of neurofilaments in axons of retinal cell neurons: characterization and evidence for their differential association with stationary neurofilaments. J Cell Biol 107:2689-2701.

Martini R, Bollensen E, Schachner M (1988) Immunocytological localization of the major peripheral nervous system glycoprotein $P_{0}$ and the L2/HNK-1 and L3 carbohydrate structures in developing and adult mouse sciatic nerve. Dev Biol 129:330-338.

Mata M, Kupina N, Fink DJ (1992) Phosphorylation-dependent neurofilament epitopes are reduced at the node of Ranvier. J Neurocytol 221:199-210.

Medori R, Autillio-Gambetti L, Jenich H, Gambetti P (1988a) Changes in axon size and slow axonal transport are related in experimental diabetic neuropathy. Neurology 38:597-601.

Medori R, Jenich H, Autillio-Gambetti L, Gambetti P (1988b) Experimental diabetic neuropathy: similar changes of slow axonal transport and axonal size in different animal models. J Neurosci 8:18141821.

Messing A, Chen HY, Palmiter RD, Brinster RL (1985) Peripheral neuropathies, hepatocellular carcinomas and islet cell adenomas in transgenic mice. Nature 316:461-463.
Messing A, Behringer RR, Hammang JP, Palmiter RD, Brinster RL, Lemke $G$ (1992) $P_{0}$ promoter directs expression of reporter and toxin genes to Schwann cells of transgenic mice. Neuron 8:507-520.

Messing A, Behringer RR, Wrabetz L, Hammang JP, Lemke G, Palmiter RD, Brinster RL (1994) Hypomyelinating peripheral neuropathies and Schwannomas in transgenic mice expressing SV40 T-antigen. J Neurosci 14:3533-3539.

Meyer MW, Lazzarini RA, Lee VM-Y, Schlaepfer WW, Nelson DL (1987) The human mid-size neurofilament subunit: a repeated protein sequence and the relationship of its gene to the intermediate filament gene family. EMBO J 6:1617-1626.

Mirsky R, Winter J, Abney ER, Pruss RM, Gavrilovic J, Raff MC (1980) Myelin-specific proteins and glycolipids in rat Schwann cells and oligodendrocytes in culture. J Cell Biol 84:483-494.

Mulligan L, Balin BJ, Lee VM-Y, Ip W (1991) Antibody labeling of bovine neurofilaments: implications on the structure of neurofilament sidearms. J Struct Biol 106:145-160.

Nixon RA (1993) The regulation of neurofilament protein dynamics by phosphorylation: clues to neurofibrillary pathobiology. Brain Pathol 3:29-38.

Pannese E, Ledda M, Matsuda S (1988) Nerve fibers with myelinated and unmyelinated portion in dorsal spinal root. J Neurocytol 17:693700.

Pappenheimer AM Jr (1977) Diphtheria toxin. Annu Rev Biochem 46:69-94.

Parhad I, Clark A, Griffin J (1987) The effect of impairment of slow axonal transport on axonal caliber. In: Axonal transport (Smith R, Bisby M, eds), pp 263-277. New York: Liss.

Perkins CS, Aguayo AJ, Bray GM (1981) Behavior of Schwann cells from Trembler mouse unmyelinated fibers transplanted into myelinated nerve. Exp Neurol 71:515-526.

Poduslo JF, Windebank AJ (1985) Differentiation-specific regulation of Schwann cell expression of the major myelin glycoprotein. Proc Natl Acad Sci USA 82:5987-5991.

Politis MJ, Sternberger N, Ederlc K, Spencer PS (1982) Studies on the control of myelinogenesis. J Neurosci 2:1252-1266.

Pollard J, McLeod J (1980) Nerve grafts in the Trembler mouse: an electrophysiological and histological study. J Neurol Sci 46:373-383.

Price R, Paggi P, Lasek R, Katz M (1988) Neurofilaments are spaced randomly in the radial dimension of axons. J Neurocytol 17:55-62.

Small JA, Scangos GA, Cork L, Jay G, Khoury G (1986) The early region of human papovavirus JC induces dysmyelination in transgenic mice. Cell 46:13-18.

Suter U, Welcher AA, Ozcelik T, Snipes GJ, Kosaras B, Francke U, Billings-Gagliardi S, Sidman RL, Shooter EM (1992) Trembler mouse carries a point mutation in a myelin gene. Nature 356:241-244.

Szaro BG, Whitnall MH, Gainer H (1990) Phosphorylation dependent epitopes on neurofilament proteins and neurofilament densities differ in axons in the corticospinal and primary sensory dorsal tracts in the rat spinal cord. J Comp Neurol 302:220-235.

Trapp BD, Moench T, Pulley M, Barbosa B, Tennekoon G, Griffin J (1987) Spatial segregation of mRNA encoding myelin-specific proteins. Proc Natl Acad Sci USA 84:7773-7777.

Trapp BD, Hauer P, Lemke G (1988) Axonal regulation of myelin protein mRNA levels in actively myelinating Schwann cells. J Neurosci 8:3515-3521.

Trojanowski JQ, Schmidt ML, Shin R-W, Bramblett GT, Rao D, Lee VM-Y (1993) Altered tau and neurofilament proteins in neurodegenerative diseases: diagnostic implications for Alzheimer's disease and Lewy body dementias. Brain Pathol 3:45-54.

Windebank AJ, Wood P, Bunge R, Dyck P (1985) Myelination determines the caliber of dorsal root ganglion neurons in culture. $J$ Neurosci 5:1563-1569.

Xu Z, Cork LC, Griffin JW, Cleveland DW (1993) Increased expression of neurofilament subunit NF-L produces morphological alterations that resemble the pathology of human motor neuron disease. Cell 73:23-33.

Yamasaki H, Bennett GS, Itakura C, Misutani M (1992) Defective expression of neurofilament protein subunits in hereditary hypotrophic axonopathy of quail. Lab Invest 66:734-743. 